\title{
TOMÁS DE AQUINO E BOÉCIO DE DÁCIA: LEITORES DOS CLÁSSICOS A RESPEITO DA FELICIDADE
}

Luis A. De Boni*

O problema da felicidade é recorrente nos tratados sobre Ética da Antiguidade. Os medievais defrontam-se com eles ao escreverem seus próprios textos. Neste trabalho procura-se analisar a forma como Tomás de Aquino e Boécio de Dácia, ao produzirem textos não teológicos, incorporam a seus tratados as obras antigas, principalmente de Aristóteles e Severino Boécio.
In the treatises about Ethics of ancient times, the problem of happiness is recurrent. When medieval masters wrote their texts, they were faced with them. In this article, the author tries to analyze how Thomas Aquinas and Boethius of Dacia, when they produce nontheological texts, incorporate into their treatises the ancient works, specially those of Aristotle and Severinus Boethius.

Boa parte dos pensadores contemporâneos é de opinião que na Filosofia não existe espaço para a pergunta sobre a felicidade. Em outras épocas o problema chamou bem mais a atenção: para as éticas antigas e medievais, por exemplo, este tópico constituia questão central.

No presente texto analisarei o pensamento de Tomás de Aquino e de Boécio de Dácia a respeito da felicidade, enquanto bem supremo do homem, definível pela razão. Para tanto, na primeira parte, estudarei o conceito de eudaimonia (ou beatitudo) em autores antigos, precipuamente em Aristóteles e Severino Boécio, mas também em Sêneca e Agostinho, por tratar-se de clássicos com influência direta sobre o século XIII. Numa segunda parte, deter-me-ei na Summa contra gentiles de Tomás de Aquino. Enfim, em um terceiro momento, o De summo bono de Boécio de Dácia será o fio condutor.

\section{1 - A felicidade: de Aristóteles a Severino Boécio}

1.1 - Aristóteles pergunta-se sobre a felicidade, e dela trata ex-professo, nas duas Éticas. Chama a atenção o fato de que a questão é levantada no início da Ética a Nicômaco, à qual me atenho, mas depois é deixada de lado, só retornando nos capítulos finais do livro X. Ao esboçar uma resposta, sente-se na obrigação de cla-

- Pontifícia Universidade Católica do Rio Grande do Sul - PUCRS - Porto Alegre.

v. 40

$n^{2} 159$


rear conceitos, e o faz com tal maestria, que os transformou em moeda corrente nos séculos posteriores. ${ }^{1}$

O bem, diz ele, é aquilo que todas as coisas desejam e, por isso, o bem é o fim da ação humana. $\mathrm{E}$ como nos fins não se pode regredir ao infinito, e existe um fim de nossas ações que queremos por ele mesmo, devemos dizer que tal fim é o bem supremo ${ }^{2}$ e, enquanto tal, é também a felicidade. Mas há diferentes opiniões sobre a felicidade, sendo que alguns a colocam no prazer, outros, na vida segundo a virtude, como se exige do cidadão, e outros, enfim, na vida de contemplação. ${ }^{3}$ Podese tentar dirimir a questão dizendo que "o bem humano consiste em uma atividade da alma conforme a excelência própria do homem e, se há muitas virtudes ou excelências, então conforme a melhor e mais perfeita, [...] numa vida completa". ${ }^{4}$ Acrescente-se ainda que seja algo que possa ser alcançado por muitos e tenha uma certa estabilidade. Uma felicidade, enfim, tal como é possivel nesta vida. ${ }^{5}$

Retomando o tema no final da obra, pergunta-se inicialmente a respeito do prazer. Vê-se pelas colocações apresentadas, que a palavra para ele é multívoca, pois em outros tópicos condenara o prazer, por reduzir o homem à condição dos animais. Agora, descendo a minúcias, sustenta que é algo concomitante à ação e que a complementa, sendo bom ou mau conforme o objeto a que se refere, pois a atividade é especificada pelo objeto. ${ }^{6}$ Passa depois a tratar da felicidade, observando outra vez que ela é uma atividade conforme a virtude mais elevada do homem. Ora, tal virtude parece ser o intelecto, o qual, ou é a própria divindade, ou algo divino no homem. O exercício mais elevado desta faculdade não consiste propriamente no descobrimento da verdade, ou na procura dela, mas na sua contemplação. Deus, portanto, que supera a todos os seres em felicidade, não possui outra atividade além da contemplação, e entre os homens, aqueles que primam pela atividade do intelecto são também os mais felizes, e quanto mais se lhes desenvolve a capacidade de contemplar, mais felizes se tornam.

Os textos a respeito da vida contemplativa (biós theoretikós), tomados isoladamente, parecem cristalinos. Contudo, quando examinados no conjunto da obra, levantam algumas dúvidas. Para alguns, constituem eles uma concessão feita pelo autor à vida filosófica, e formam quase um apêndice, que acaba por tirar a unidade da obra. Para outros, a felicidade encontra-se na vida virtuosa, que não depende

1 A obra aristotélica è de difícil leitura e sujeita a inúmeras interpretações. Veja-se, a respeito da questão da felicidade, entre outros estudos: Armin, H. von. Nochmals die aristotelischen Ethiken. Wien-Leipzig, 1929; Dirlmeier, F. Nikomanische Ethik. Berlin, 1956; Düring, I. Anistoteles: Darstellung und Interpretation seines Denkens. Heidelberg, 1966; Jaeger, W. Anistoteles: Grundlegung einer Geschichte seiner Entwicklung. Berlin, 1923; Gauthier, R. e Jolif, Y. L'Éthique a Nicomaque. Paris, 2. ed. 1970; Guariglia, O. Ética y Política según Anistóteles. Buenos Aires, 1992; Mansion, A. "L'existence d'une fin demière de l'homme et la morale." In: Revue phil. de Louvain, 48 (1950), p. 465-477.

Ética a Nicômaco 1. I, c. 2, 1094b.

3 ibid. c. $4-5 ; 1295 a-1296 a$.

4 ibid. c. 7, 1098a.

5 beatos ut homines, diz o texto latino (ibid. c.10, 1101a).

6 l. X. c. 1-5, 1172a-1176a.

7 ibid. c. 6-9, 1176a-1179a. 
de todo da vida contemplativa. Outros ainda julgam que à felicidade pertencem a vida virtuosa e a contemplação, conjuntamente. Outros, enfim, são de opinião que a vida de prazer, a vida segundo as virtudes morais e a vida contemplativa, no conjunto, são o ideal de vida para Aristóteles, cabendo o primado à contemplação, situando-se as virtudes morais como meios com relação ao fim (com isso estaria mantido o ideal platônico do filósofo rei, mas não se obedeceria à exigência de que a felicidade seja um bem ao alcance de muitos).

Em todas estas hipóteses interpretativas, porém, não se altera a concepção que Aristóteles tem da theoría, como algo de todo imanente à atividade humana. A divindade contemplada não possui nada de transcendental: ela se encontra ao alcance do homem, nos limites da pura razão, longe, pois, de qualquer ideal místico, ou da contemplação platônica, que fala em ir além do ser, para chegar até a fonte do bem. Para Aristóteles, nada existe que esteja além da razão e, por isso, a contemplação é um ato puramente racional. Contemplar é a atividade própria da inteligência humana e, para um grego, seria um contra-senso tanto afirmar que a virtude suprema da contemplação possui uma virtude que lhe é ainda superior, como afirmar que o homem possui algo que o transcende. Se Deus é o objeto da contemplação e, enquanto tal, é a felicidade do homem, não o é por ser ele o ser supremo, mas por ser o objeto mais adequado à divindade do intelecto humano. ${ }^{8}$

O projeto aristotélico resume-se, portanto, numa pergunta a respeito da felicidade intramundana. Parágrafos fora do contexto podem eventualmente levar a uma outra leitura, que não é, seguramente, a do autor. O que para ele interessa, é definir em que consiste a felicidade dos homens, enquanto homens, aquilo que os torna felizes na medida possivel aos homens, beatos ut homines.

1.2 - O debate a respeito da felicidade, dentro do pensamento pagão pós-aristotélico, recebeu novos aportes principalmente através do estoicismo e do epicurismo. Devido à influência posterior sobre o Cristianismo, atenho-me somente ao primeiro.

Para o estoicismo, seguir a própria natureza constitui a lei primeira, a cuja imanência reduz-se não só qualquer projeto de vida, como também toda e qualquer concepção de divindade, visto que Deus e a natureza identificam-se. ${ }^{9}$ Seguir a Deus é seguir a natureza. O homem feliz é aquele que segue a natureza, tal como ela se apresenta, visto que não há distinção entre ser feliz e viver segundo a natureza. ${ }^{10}$ Esta nos ensina que cabe ao homem viver acima das coisas transitórias, olhando altaneiro tanto para as que causam prazer, como para as que causam dor, pois tudo o que pertence ao reino do mutável não constitui o cerne da grandeza

8 Gauthier, R. e Jolif, Y. op. cit. p.856.

9 "Ouod inter omnes Stoicos convenit, rerum naturae adsentior; ab illa non deerrare et ad illius legem exemplumque formari sapientia est" (Sêneca, De vita beata II, 3, citado pela ed. Obras Completas de Seneca I - Tratados Morales. México: UNAM, 1944). Ao analisar o estoicismo, atenho-me a este texto, quer por tratar-se de uma obra específica sobre o tema, quer porque o autor exerceu influência direta sobre a patrística latina. A respeito do estoicismo, cfr. Sanson, V. F. Estoicismo e Cristianismo (Caxias do Sul: EDUCS, 1988), principalmente o cap. V (pp. 90-102), onde aborda as diferenças entre ambos.

10 "[...] idem est ergo beate vivere et secundum naturam" (ibid. VIII, 1). 
humana. Cabe levar com igualdade de ânimo tanto o sofrimento que por natureza tornou-se inevitável, como também o prazer que eventualmente acompanha alguma ação. Se a felicidade perfeita exclui de si o prazer, porque ela se caracteriza pela constância e permanência de um estado de espirito, enquanto o prazer apresenta-se como volúvel. Ele é algo que, quando sobrevém ao homem, não precisa ser rejeitado, mas de modo algum a obtenção do prazer pode ser colocada como fim do agir humano. Aliás, o sábio, que é tal por viver acima das coisas transitórias da vida, tem consciência de que a liberdade, tão difícil de ser obtida, é algo que faz com que o prazer que acompanha a operação seja-lhe tardio, pequeno e tênue. ${ }^{11}$ A leitura que Sêneca faz do prazer situa-se, como se pode constatar, em momento anterior a Aristóteles; ela nada tem a ver com o prazer concomitante à ação.

O homem é feliz quando não depende de nada que seja exterior, e que de fora possa atingi-lo: quando nada deseja, e nada teme de tudo quanto lhe possa sobrevir. Recolhido em si mesmo, age sempre do mesmo modo, quer caia sobre si a felicidade, quer a desgraça. As mutações da fortuna são fúteis e despreziveis, indignas da consideração do verdadeiro sábio. O comum dos mortais preocupa-se com elas, o sábio as ignora. O vulgo é escravo das riquezas, o sábio é senhor delas. Tiradas as riquezas, tira-se tudo do homem comum; do sábio, tiradas as riquezas, tiram-se apenas alguns objetos sobressalentes, que não lhe determinam a vida, que não o tornam nem feliz, nem infeliz. Mede-se o valor do homem por aquilo que possui em si mesmo, não pelas coisas exteriores, as quais, tanto as que parecem boas, como as que parecem más, merecem o mesmo tratamento. ${ }^{12}$

1.3 - Sob as aparências de uma mesma linguagem, a pergunta sobre a felicidade passa a ser tratada de forma radicalmente diferente pelo Cristianismo.

Se em Sêneca, de certa forma, compila-se o pensamento estóico do mundo greco-romano, em Agostinho resume-se o pensamento cristão dos primeiros séculos. Em seu diálogo De beata vita , escrito logo após a conversão, o neoplatonismo e o estoicismo incorporam-se à tradição elaborada por Justino, Clemente, Orígenes e Ambrósio. ${ }^{13} \mathrm{O}$ ideal de vida do mundo pagão está-lhe ainda próximo, talvez próximo demais, e a conversão ainda não desabrochou de todo. Mas as linhas gerais da síntese agostiniana já se anunciam.

A felicidade não se encontra nas coisas passageiras, que hoje são e amanhã não existem mais. $\mathrm{O}$ que se encontra sujeito ao fluxo do tempo leva consigo o caráter de transitório, e nele o espírito humano não pode descansar. ${ }^{14} \mathrm{Se}$, pois, alguém quer ser feliz, deve procurar bens outros que não os que podem vir a ser ar-

11 "[...] sapientium remissae voluptates et modestae ac paene languidae" (ibid. XII, 2).

12 "Summum bonum est animus fortuita despiciens, virtute laetus [...] beatum dicamus hominem eum, cui nullum bonum malumque sit nisi bonus malusque animus, honesti cultorem, virtute contentum, quem nec extollant fortuita nec frangant, qui nullum maius bonum eo quod sibi ipse dare potest noverit, cui vera voluptas enit voluptatem contemptio" (ibid. IV, 1).

13 Cfr. De beata vita. Obras de San Agustin. vol. I. Ed. de Vitonino Capanaga. Madrid: BAC, 1969. p. 535-586.

14 Id ergo [...] semper manens, nec ex fortuna pendulum, nec ullius subiectum casibus esse debet. Nam quidquid mortale et caducum est, non potest a nobis quando volumus et quandiu volumus haberi (De beata vita 2, 11). 
rebatados pela fortuna. ${ }^{15} \mathrm{O}$ homem que conhece como se deve viver, o sábio, é aquele que se afasta do transitório e volta sua satisfação para o que é durável. Nada lhe falta, nada atinge seu ânimo: se possui bens materiais, aceita-os; se deles está privado, nem por isso se abala. Nada do que lhe é exterior o afeta: nem a dor, nem a morte: evita o mal que pode evitar, e aceita o inevitável, pairando soberano tanto sobre um como sobre outro. ${ }^{16}$

O sábio é aquele para quem não existe penúria,aquele a quem nada falta. Se a penúria, a necessidade, tivesse como oposto a riqueza, então o opulento seria sábio. Mas a quantidade de bens materiais não supre de modo algum a carência de sabedoria de alguém, pois, na verdade, o oposto da necessidade é a plenitude: aquela medida interior, única que torna o homem feliz. A sabedoria, portanto, encontra-se não em bens exteriores, mas na plenitude, a ser buscada no interior do homem, e quem possui a sabedoria, de nada carece. ${ }^{17}$ Mas que é a sabedoria? É uma medida da alma, um modus animi, que a mantém no equilíbrio entre o pouco e o excessivo.

A linguagem, até aqui, não se diferencia da dos estóicos. Mas então, de repente, há uma guinada, quando o autor pergunta se existe alguma sabedoria que mereça ser tida como tal, a não ser a sabedoria de Deus. ${ }^{18}$ Já no primeiro capítulo do diálogo, observara ele que a felicidade é possuir a Deus. Agora, acrescenta que, por revelação divina - portanto, não mais graças ao esforço humano - sabemos que o Filho é a sabedoria de Deus, e que a Sabedoria é a Verdade de Deus, verdade esta que encerra a medida suprema, da qual procede e à qual retorna. Afastando-se, pois, da imanência do pensamento pagão, Agostinho coloca a felicidade num mundo que transcende a existência terrena: o homem deixa de ser a medida de todas as coisas, e passa a ser medido pelo metro da sabedoria divina. Pode-se continuar afirmando que a felicidade, como estado de plenitude, localiza-se e deve ser buscada no interior do homem, mas ela não é totalmente do homem, porque se encontra naquele lugar onde ele, ao procurar a si mesmo, encontra Deus: ela é um dom de Deus, a doação que Deus faz de si mesmo. ${ }^{19}$

A mudança é radical. Não se trata mais de realizar-se humanamente através de uma atitude impassivel ante os bens exteriores: é necessário ir além deles. Nem se almeja um estado permanente de bem-estar limitado à vida terrena: é algo que se encontra além desta vida. Nem será obtida a felicidade graças ao exclusivo esforço de quem a procura: ela é, acima de tudo, um dom de Deus. No mundo pa-

15 [...] si quis beatus esse statuit, id eum sibi comparare debere quod semper manet nec ulla saeviente fortuna eripi potest (ibid. 2, 11).

16 "Non enim eis eget ipse animus, in quo posita est vita beata. Ipse enim perfectus est; nullus autem perfectus aliquo eget et quod videtur corpori necessarium sumet, si adfuerit; si non adfuerit, non eum istanum rerum franget inopia. Omnis namque sapiens fortis est; nullus autem fortis aliquid metuit. Non igitur metuit sapiens aut mortem corporis aut dolores, quibus pellendis vel vitandis vel differendis sunt necessaria illa, quorum ei potest contingere inopia" (De beata vita 4, 25).

17 ibid. 4, 23-31.

18 "Ouae est autem dicenda sapientia, nisi quae Dei Sapientia est?" (ibid. 4, 34).

19 "Praemium Dei, ipse Deus est" (C. C. t. 39, 1002, 21); "Noli aliquid a Deo quaerere, nisi Deum" (Sermo 19,5; PL 38, 136). 
gão, ao elaborar-se o conceito de perfeição divina, foi necessário excluir de Deus, ou dos deuses, toda a espécie de desejo, pois o desejo implica imperfeição. Também o amor, como aspiração de um ser imperfeito, tendente à perfeição, não poderia existir em Deus ou, se existisse, seria um érôs, um amor de si mesmo, fechado em si mesmo. Agostinho, fiel à tradição bíblica, afirma, ao contrário, que pertence à perfeição divina o amor de Deus para com os homens. Deus não somente é capaz de amar: Deus é amor. A felicidade, para tornar-se um ascensus do homem a Deus, precisa ser antes um descensus de Deus até o homem, uma obra de pura graça. ${ }^{20} \mathrm{O}$ homem feliz não é o que atingiu a ataraxia, ou a apathia: "feliz é aquele a quem Deus manifestou a sua misericórdia". ${ }^{21}$

1.4 - Útimo eco da antiguidade, Severino Boécio dedica ao tema o livro II da Consolação da Filosofia. ${ }^{22}$ O projeto do autor é ater-se ao plano puramente filosófico. Conhecedor da literatura a respeito, assume-a toda na redação da obra, em forma de diálogo, onde prima a influência do neoplatonismo.

Ao iniciar sua fala, a Filosofia, um dos personagens do diálogo, apresenta alguns conceitos tradicionais, tomados como pressupostos, ao dizer que se encontra ínsito na natureza humana o desejo do bem, que o bem é o fim a que todos almejam chegar e que este fim é a felicidade. E anexa a conhecida definição: "A felicidade consiste num estado perfeito pela congregação de todos os bens". ${ }^{23}$ A vida toda dos homens transcorre na busca da felicidade, mas, transviados no mundo, eles se parecem com os bêbados, que não encontram o caminho de volta para o próprio lar. Nesta situação lançam-se aos bens exteriores, julgando que lá reside a felicidade. Neles, porém, não se encontra o bem supremo, pois o bem torna bons os que o possuem, tal como a virtude torna virtuosos os que a possuem; as coisas exteriores, entretanto, são concedidas pela volubilidade da fortuna tanto aos bons como aos maus. Ou então os mortais procuram os prazeres físicos ou os bens corpóreos, nos quais não nos distinguimos dos animais.

A felicidade - prossegue a Filosofia - não pode encontrar-se em algo fraccionado e múltiplo, mas num bem único, que não provém de coisas exteriores, e que encerra em si a plenitude de tudo o que se possa desejar. E surge então a pergunta fatal, no caso, talvez, de inspiração mais platônica que cristã: "Crês que nestas coisas mortais e caducas haja algo que possa realizar uma condição deste tipo?" "24 $^{24}$ constatar que Boécio, graças ao processo maiêutico do diálogo, descobrira onde se encontra a verdadeira felicidade, a Filosofia, reportanto-se ao Timeu, entoa o célebre canto IX: "O qui perpetuam mundi", que constitui o ponto axial não só do livio III, mas de toda a obra: um hino de ação de graças, que se conclui com a invoca-

20

21

22

Cfr. Becker, Aimé. De l' instinct du bonheur à l' extase de la beatitude. Paris: Lethielleux, 1967. p. 302.

Comm. in ps. 84,9 (C. C. 39,1167 ).

Sigo o texto latino da edição A. M. Severino Boezio. La consolazione della Filosofia. O. Dallera (trad.). Milano: Rizzoli, 3a. ed. 1984, que se baseia na edição critica de K. Buechner, Heidelberg: Editiones Heidelbergenses, 1947.

"[...] esse beatitudinem statum bonorum omnium congregatione perfectus" (ibid. prosa 2).

"Essene aliquid in his mortalibus caducisque rebus putas, quod huius modi statum possit afferre?" (ibid. prosa 8). 
ção: "Concede, ó pai, à minha mente elevar-se à tua sublime morada; concede que eu possa atravessar a fonte purificadora do bem e, descoberta a luz, que eu possa fixar em ti os olhos atentos de meu espirito. Dissolve as névoas e o peso de minha massa terrena e refulge em teu esplendor; pois tu és a serenidade, tu és o repouso tranqüilo para os justos; contemplar-te é o nosso fim; tu que és, ao mesmo tempo, o princípio, o sustentáculo, o guia, o caminho e a meta". ${ }^{25}$

Feita a descrição do verdadeiro bem, trata-se de saber se ele existe de fato. $O$ texto converte-se, daí em diante, em um tratado de Teodicéia. A palavra Deus, até então quase omitida, passa a ser usada, e a existência dele é demonstrada pelas noções de perfeição (se sabemos que algo é mais ou menos perfeito, é porque o comparamos com a própria perfeição), e de emanação (a natureza procede do mais perfeito para o menos perfeito).

Deus é o bem supremo, acima do qual não pode existir outro, pois se outro existisse, a este é que se deveria chamar de Deus. $\mathrm{E}$ como fora dito anteriormente que a felicidade é o bem supremo do homem, torna-se então necessário concluir que Deus é a felicidade. O modo humano de pensar poderia, talvez, representar a Deus, como alguém que recebe de fora a felicidade; porém, na realidade, ela não é algo que se lhe acrescenta, mas constitui a própria essência dele, pois tudo o que se atribui a um ser absolutamente simples, deve ser dito como constituindo sua essência. Portanto, Deus não possui a felicidade, ele é a felicidade. E como a felicidade e o bem supremo se identificam, então o bem, a felicidade e Deus são a mesma coisa. Se é verdadeiro que o homem é feliz quando chega à felicidade, é também verdadeiro que, como Deus e a felicidade são idênticos, o homem, por participaÇão, se torna Deus ao atingir a divindade. ${ }^{26}$

Neste contexto, os bens parciais só podem ser considerados bens, enquanto tendem para a unidade, de modo que, ao querer-se um deles, querem-se todos os demais, pois os bens menores são bens na medida em que participam da unidade do bem supremo. Não são partes do bem maior, que não se constitui de partes, mas ordenam-se a um único bem. E como [concordando com Aristóteles] o bem é aquilo que todas as coisas desejam, ${ }^{27}$ e como todas desejam também a unidade, deduz-se que o bem e o uno identificam-se.

A unidade, para a qual os seres tendem, mostra que alguém, dotado de unidade, criou e, "com o timão de sua bondade", ordenou devidamente as coisas do mundo, que alguém foi capaz de reunir e unir coisas tão diferentes, de modo a que tenham um sentido. Quem fez isso foi a providência divina. Principio imóvel, regula por si mesmo, de modo perfeito, sem auxilio de nada exterior, a multiplicidade das mutações.

" $\mathrm{Da}$, pater, augustam menti conscendere sedem, da fontem lustrare boni, da luce reperta in te conspicuos animi defigere visus. Dissice terrenae nebulae et pondera molis atque tuo splendore mica; tu namque serenum, tu requies-tranquilla piis, te cernere finis, principium vector dux semita terminus idem" (ibid. canto IX). "Nam quoniam beatitudinis adeptione fiunt homines beati, beatitudo vero est ipsa divinitas, divinitatis adeptione beatos fieri manifestum est. [...] Omnis igitur beatus deus. Et natura quidem unus; participatione vero nihil prohibet esse quam plurimos" (ibid. prosa 10).

27 "Cuncta igitur bonum petunt, quod quidem ita describas licet ipsum bonum esse, quod desideretur ab omnibus" (ibid. prosa 11). 
Aquele que é o princípio, constitui também o fim dos homens, embora estes não o percebam claramente, ${ }^{28}$ porque o procuram onde ele não se encontra. Procuram-no fora de si mesmos, quando deveriam voltar para dentro de si a luz da visão interior, pois quando se deseja perquirir a verdade, no que ela tem de mais profundo, é preciso penetrar nos recônditos do espirito humano: o que se deseja encontrar fora de si, encontra-se já no tesouro da própria interioridade (Agostinho que o diga]. ${ }^{29}$ Se os homens, como foi observado no inicio, parecem-se com os bêbados, que cambaleando procuram o caminho de volta ao lar, Boécio pode dar-se por feliz, ao constatar que agora conhece o caminho, ou melhor, volta a saber qual seja o caminho, e, por isso, julga-se duplamente grato a Platão: em primeiro lugar, porque este ensinou que aprender é recordar, embora não se tenha consciência, e assim o autor, durante a vida, aprendeu de onde provinha e para onde se dirigia; em segundo lugar, porque o mesmo Platão fez com que novamente recuperasse a memória, que havia perdido devido ao peso do sofrimento. ${ }^{30}$ Quando, porém, o homem sabe o que é o sumo bem, onde ele se encontra, e como chegar a ele, então a Filosofia pouco ainda tem a ensinar-lhe, e ele, "cheio de felicidade, já pode voltar à pátria". ${ }^{31}$ Esta conclusão neoplatônico-agostiniana é a última palavra de Boécio a respeito da felicidade.

\section{2 - Tomás de Aquino: 0 aristotélico além de Aristóteles}

Tomás de Aquino é um metafísico do estofo de Aristóteles e Agostinho, mas os supera enquanto sistemático - o que em parte se explica pela forma do trabalho dos acadêmicos medievais: a inspiração cristã de sua Filosofia garantia-lhes uma visão unitária e global do ser, do saber e da vida, que se sintetizava no manual que lhes servia de fio condutor, o Livro das Sentenças de Pedro Lombardo. Tomás desenvolveu seu pensamento sobre a felicidade principalmente nos estudos de ética da Summa contra gentiles e da Summa theologiae. De fundamental importância para seu trabalho foram os comentários literais, apostos à obra de Aristóteles, na In decem libros Ethicorum Aristotelis ad Nicomachum expositio. Valho-me da Expositio e da Summa theologiae como textos auxiliares, atendo-me principalmente à Summa contra gentiles, pelo fato de que ela, se comparada à Expositio, mantém maior liberdade ante o texto aritotélico e, com relação à Summa theologiae, por dizer explicitamente que, nos três primeiros livros, haverá de proceder valendo-se de argumentos aduzidos pela razão - não pela revelação. ${ }^{32}$

28 "Vos quoque, o terrena animalia, tenui licet imagine vestrum tamen principium somniatis verumque illum beatitudinis finem licet minime perspicaci" (ibid. prosa 3).

"Quisquis profunda mente vestigat verum cupitque ille deviis falli, in se revolvat intimi lucem visus longosque in orbem cogat inflectens motus animumque doceat, quicquid extra molitur, suis retrusum possidere thesauris" (ibid. canto 11).

ibid. prosa 12

31 "Cum haec, inquit, ita sentias, parvam mihi restare operam puto, ut felicitatis compos patriam sospes revisas" (ibid. prosa 12).

32 SCG I, c. IX. - A obra vem citada pela edição preparada por C. Pera, P. Marc e P. Caramello. Torino: Marietti, 1961. A Suma teológica, pela edição por mim revista. Porto Alegre: EST, 1980-81. A In decem libros Ethicorum Aristotelis ad Nicomachum expositio pela edição preparada por R. Spiazzi. Torino: Marietti, 1949. 
A fonte primeira do tratado do Aquinate é, sem dúvida, Severino Boécio, que lhe forneceu um modelo acabado de desenvolvimento do tema. Entretanto, seguindo as técnicas de redação da época, e seu hábito de omitir fontes, Tomás cita apenas uma vez o livro III do De consolatione..$^{33}$ Se o esquema é boeciano, a argumentação é aristotélica: chama a atenção o fato de que Tomás converte a linguagem neoplatônica de Boécio (e também de Agostinho e de Dionísio) em linguagem peripatética, de tal forma que só uma leitura comparativa minuciosa permite perceber, na maioria dos casos, que determinado capítulo da Contra gentiles encontra paralelo em tópico do pensador romano.

Dentro do teleologismo clássico, Tomás observa que todo o agente age por um fim. O fim é aquilo onde descansa o apetite do agente e do que é movido. Ora, é da natureza do bem que seja ele o término do apetite. Conclui-se, pois, que o bem e o fim se identificam. Mas na ordem dos fins não se pode proceder ao infinito, devendo-se chegar a um fim último, que é único, querido por si mesmo e não em função de outro. Este fim supremo é também o bem supremo.

Observe-se, porém, que o bem supremo do homem não se encontra nem em algo que lhe vêm do exterior, e que por isso não o torna necessariamente melhor ou pior, e é em grande parte devido à fortuna; nem nos prazeres, nem nos dotes físicos. Concordando com Aristóteles, afirma que o bem supremo é algo a ser alcançado pelo que há de mais nobre no homem, e tal é, sem dúvida, o intelecto. De fato, o intelecto é o que existe de específico no homem, e a operação específica de cada ser é seu fim, por ser sua perfeição segunda. E como a operação é especificada pelo objeto, conclui-se que o fim do homem é conhecer o que existe de mais perfeito na ordem do inteligível. ${ }^{34}$

Tomás afirma, então, que a contemplação de Deus é a felicidade do homem. Ora, esta conclusão força o texto aristotélico, ao interpretar o vivere secundum virtutem, como sendo referência à virtude dianoética suprema, e prescrevendo às virtudes morais a função de meio na hierarquia da busca da felicidade. Com isso, a oscilação da Ética a Nicômaco entre a vida virtuosa e a vida contemplativa fica resolvida, e introduz-se unidade no texto. Não se detendo ai sua leitura com outras lentes, encontra na própria argumentação do Estagirita o fundamento para a dis-

33 Na Suma teológica I-II, qq. 1-5, são numerosas as citaçōes do texto boeciano. Também são raras as semelhanças textuais, como, por exemplo: "Nec exterioris adminiculo indiget" (SCG II, 2) e "nullis extrinsecus amminiculis indigebit" (De consolatione III, canto 12). Na estrutura do texto, no entanto, é bem mais visivel a influência de Boécio. Assim, por exemplo, a questão do mal, que neste é aventada no incio do livro IV, em continuação ao tratado sobre a felicidade, na Contra gentiles fica no mesmo contexto, sendo inserida dentro do tratado, ao ser examinado o axioma de que "todo o agente age em vista do bem". Ora, na Expositio a questão só é mencionada numa observação ao livro IV, c. 11 , na lição 13 (op. cit. n. 808, p. 223), e na Summa theologiae os textos paralelos são relegados para as questōes a respeito do pecado. A mesma influência é observada na pergunta sobre onde não se encontra a felicidade: ao tratar dos bens exteriores, do prazer e dos bens do corpo, Tomás, nas duas Sumas, segue a mesma enumeração de Boécio, embora variando a ordem.

34 "Propria operatio cuiuslibet rei est finis eius: est enim secunda perfectio ipsius; unde quod ad propriam operationem bene se habet, dicitur virtuosum et bonum. Intelligere autem est propria operatio substantiae intellectualis. Ipsa igitur est finis eius. Quod igitur est perfectissimus in hac generatione, hoc est ultimus finis[...].Cum autem huiusmodi operationes ex obiectis speciem recipiant, per quae etiam cognoscuntur, oportet quod tanto sit perfectior aliqua istarum operationum, quanto eius obiectum est perfectius. Et sic intelligere perfectissimum intelligibile, quod Deus est, est perfectissimum in genere huius operationis quae est intelligere" (SCG II, c. 25). 
tinção entre a felicidade nesta vida e a felicidade na vida futura. Aristóteles pergunta-se sobre a felicidade que é possivel ao homem nesta vida, e nada mais. Tomás observa que nenhum dos bens da presente existência satisfaz plenamente ao homem, e que a natureza teria agido em vão, se o desejo de felicidade plena, ínsito em todos, não tivesse como realizar-se. Portanto, o único modo de dizer que não é vão o desejo de felicidade, é colocá-la a esta na vida futura. ${ }^{35}$

A argumentação é altamente elaborada, construindo a partir de premissas colocadas nos tratados anteriores. Para se falar do fim ao qual tendem as criaturas, torna-se necessário falar do princípio do qual procedem, pois "do mesmo modo e ordem como as coisas provêm do primeiro princípio, reordenam-se para o último fim, visto que o primeiro princípio e o último fim das coisas é o mesmo" ${ }^{36}$ Portanto, se o princípio das coisas está em Deus, também o fim delas deve encontrar-se nele. Mas dizer que o fim das coisas é Deus, significa dizer que as coisas tendem a assemelhar-se a ele, pois, como afirma Aristóteteles, "a forma do que gera é o fim da geração", ${ }^{37}$ e, por isso, "o agente é chamado fim do efeito, enquanto o efeito tende à semelhança do agente".$^{38}$ Há portanto uma correspondência intrínseca entre 0 fato de que $o$ efeito tenda à semelhança do agente e $o$ de que $o$ agente assemelhe a si 0 efeito. ${ }^{39}$ Esta semelhança o homem a adquire ao unir-se a Deus pelo ato de sua virtude mais elevada, que é o intelecto, e por isso Aristóteles colocou como felicidade do homem a contemplação da divindade.

Se, porém, considerarmos o modo como nesta vida se realiza a operação do intelecto, constataremos que ela é imperfeita, visto que nossa inteligência encontra-se sempre em potência: por mais que conheçamos, sempre existe algo que ainda pode vir a ser conhecido. Ora, a potência indica imperfeição, enquanto a operação, perfeição segunda do ser, leva a potência à plenitude. Se, então, a felicidade do homem for colocada no conhecimento que se pode ter de Deus neste mundo, conclui-se que ela é imperfeita, porque é sempre possivel que se desloque de algo conhecido para algo ainda não conhecido. O fim último, ao contrário, quando alcançado, põe termo ao desejo natural, de modo a que nada mais se queira, porque nada mais existe em potência de ser conhecido.

Resumida à existência terrena, a verdadeira felicidade torna-se impossivel. Contudo, se admitirmos que a inteligência, embora unida à matéria, não depende dela em seu existir, podemos então concluir que nossa inteligência, separando-se

35 São inúmeras as referências à distinção entre "esta vida" e "outra vida". Assim, por exemplo: "quod ultima felicitas quam homo in vita ista acquirere potest" (SCG III, c. 44); "non habetur quod Deus videatur secundum suam substantiam in ista vita" (ibid. c. 47; cfr. ibid. c. 63). 0 mesmo acontece tanto na Summa theologiae I-II, q. 3, a. 2, ad 4um; a. 8, in c.; q. 4, a. 5, in c.; a. 6, in c. a. 7, in c., a. 8, in c.; q. 5 , a. $3 ;$ a. 4 , in c. et ad 1um; a. 5 , in c.; quanto na Expositio 1. 1, lect. 10; lect. 15; lect.16; 1 . 2, lect. 8; 1. 10, lect. 11; lect. 13:"Attendendum etiam quod in hac vita non ponit [Aristoteles] perfectam felicitatem, sed talem qualis potest competere humanae et mortali vitae".

36 "Eodem modo et ordine quo res exeunt a primo principio reordinantur in ultimum finem, cum idem sit principium et ultimus rerum finis" (De pot., q. 3, a. 3, ob. 1).

37 II Phys. 7, 198 a 25-26.

38 SCG, loc. cit. c. 19. Também esta afirmação baseia-se em Aristóteles, que diz: "agens agit sibi simile" (I De gen. 7, 324a).

39 "Eiusdem rationis est quod effectus tendat in similitudinem agentis et quod agens assimilet sibi effectus" (SCG, loc. cit. c. 21). 
do corpo, poderá ter o conhecimento das coisas espirituais sem ter que valer-se do recurso dos sentidos. ${ }^{40}$ Noutras palavras: poderá conhecer a Deus.

Mas mesmo na outra vida a constituição natural do intelecto continuará a mesma, isto é, ele estará em potência para novos conhecimentos. Ora, o que se encontra em potência, tende para 0 ato, e até que não se encontre todo em ato, não terá atingido o fim último. ${ }^{41}$ Aristóteles já perceberá claramente o problema; por isso, atribuindo ao homem apenas uma felicidade relativa, afirmou que Deus, felićssimo em si mesmo, era ato puro, puro conhecimento de si mesmo, ou melhor, usando sua linguagem, conhecimento de conhecimento. A teologia cristã, para salvar a plenitude divina na relação de Deus com o mundo, argumentou que Deus, conhecendo a si mesmo, conhece em si todas as coisas, de modo que sua perfeição não é afetada por mudanças que venham a ocorrer entre os seres criados. A felicidade perfeita, portanto, somente poderá existir para o homem se seu intelecto, à semelhança do divino, houver esgotado as possibilidades de novos conhecimentos, estando todo em ato. Tal, porém, é naturalmente impossível ao homem, pois ao conhecer a própria essência, não conhece nela as demais coisas, e por sua natureza não pode conhecer a essência de Deus. Entretanto, a única maneira de elevar a inteligência ao ato perfeito seria conhecer a essência de Deus, e nela conhecer todas as coisas. Ou se admite, então, que não existe a felicidade perfeita, ou, para que o desejo dela não seja em vão, algo a mais deve ser acrescentado à própria natureza humana: ${ }^{42}$ é necessário que a liberalidade divina se abra para o homem e este, então, contemplando a essência de Deus, repousará de todo o desejo, pois sua inteligência será excedida pelo infinito que a informará. ${ }^{43}$ Vendo a essência divina, o homem verá nela todas as coisas à maneira como Deus as vê: num ato único, contínuo e eterno. ${ }^{44}$

Com isto, Tomás de Aquino admite que, no íntimo da natureza humana, como constitutivo dela, encontra-se a capacidade para o sobrenatural: a abertura ao sobrenatural pertence ao natural do homem. O homem não é de todo corrompido. Mesmo no estado de pecado, tem sede do absoluto. Explica-se assim por que o autor colocou o tratado sobre a graça no final do livro III da Contra gentiles, e não no livro seguinte, que trata das verdades reveladas: sem que Deus o manifestasse, o homem jamais teria a menor noção da Trindade ou da Encarnação; entretanto, mesmo sem a revelação, percebe em si o vazio do infinito.

0 que Agostinho fizera com a terminologia estóica, Tomás o fez com a peripatética: palavras, conceitos e imagens são de Aristóteles; o pensador grego é continuamente citado e mais de um leitor bem informado considerou Tomás um mero

40 ibid. c. 45.

41 "Omne quod est in potentia, intendit exire in actum. Quandiu igitur non est ex toto factum in actu, non est in suo fine ultimo [...] Ergo [intellectus noster] non erit ex toto in actu, nec in ultimo suo fine, nisi quando omnia [..] cognoscat" (ibid. c. 48).

42 "[...] oportet eius naturae aliquid superandi" (ibid. c. 53).

43 "... /quilibet tamen ita perfecte eum videt quod impletur tota capacitas naturalis: quinimmo ipsa visio omnem capacitatem naturalem excedit" (ibid. c. 59).

44 "[...] quia una et continua et sempitema operatione in illo beatitudinis statu mens hominis Deo coniungitur" (STh, I-II, q. 3, a. 2 ad 4um; cr. q. 5, a. 5 ad 1um); valendo-se da expressão de Agostinho diz também: "omnem scientiam nostram uno simul conspectu videbimus" (SCG, loc. cit. c. 60). 
aristotélico. Os conteúdos, porém, são totalmente diversos. O Aristóteles de Tomás de Aquino disse coisas que o Aristóteles histórico jamais imaginou, extraiu conclusões que nunca foram suas, embora fossem suas as premissas, porque faltaram ao pensador grego noções filosóficas fundamentais, como a de criação por bondade divina e a de providência. Por trás das mesmas palavras escondem-se dois mundos que nem sempre se harmonizam, e a afirmação de que Tomás é um aristotélico somente é válida na medida de sua correlata, quando afirma que Aristóteles foi um tomista.

\section{3 - Boécio de Dácia: é possível voltar a Aristóteles?}

Boécio de Dácia tornou-se conhecido como professor na Faculdade de Artes de Paris. Juntamente com Síger de Brabante, foi o mais atingido pela condenações de 1277, que lhe custaram a cátedra. Atenho-me ao texto específico: De summo bono. ${ }^{45}$

Se, em Tomás, o peso da tradição cristã faz com que as conclusões pareçam, por vezes, dizer mais do que a razão comporta, em Boécio há a nítida tentativa de manter-se dentro de um aristotelismo de estrita observância. Por isso mesmo, as citações e paráfrases referem-se exclusivamente a Aristóteles (há também uma referência a Averróis). Contudo, uma leitura mais atenta percebe a influência da Summa contra gentiles (e talvez da In decem libros Ethicorum Aristotelis ad Nicomachum expositio). Esta influência, em primeiro lugar, torna-se evidente de modo negativo, pelo fato de o autor, ao tratar do que constitui propriamente a felicidade, haver excluído a interpretação greco-árabe de que ela se encontra na contemplação das substâncias separadas. Ora, esta opinião, bem como uma outra, paralela a ela, que considerava o intelecto humano como perecível, unido a uma única inteligência dele distinta, era corrente na Faculdade de Artes, por volta de 1270, sendo alvo de decisões condenatórias, no dossier de 1277. Contra elas Tomás travara polêmica cerrada, negando-lhes qualquer validade. ${ }^{46}$ Parece provável, pois, que a leitura de Tomás de Aquino tenha poupado a Boécio de Dácia alguns dissabores a mais, ao fazê-lo abandonar de antemão toda referência às substâncias separadas.

Juntamente com Tomás, mantém a distinção entre "esta vida" e a "vida futura", mostrando que a Filosofia, como a entendia Aristóteles, atém-se à vida presente. ${ }^{47}$ Paralelo ao texto tomista corre também a noção de que, "assim como todas as coisas provêm da primeira causa, do mesmo modo a ela se ordenam, pois aquele ente no qual se encontra o princípio do qual tudo provém, une-se ao fim, para o qual tudo tende". ${ }^{48}$ Parece também provável a dependência quando fala que o ser

45 Boethii Daci Opera. Corpus Philosophorum Danicorum Medii Aevii. vol. VI - II. Topica et opuscula. N. G. Green-Pedersen (ed.). Hauniae: GECGAD, 1976. p. 367-377.

46 Cfr.SCG III, 41-45; II, 59-62, 73-78.

47 "Hoc enim est maius bonum quod homo a Deo recipere potest et quod Deus homini dare potest in hac vita. [...] beatitudine, quam in hac vita homini possibile esse [...] beatitudini quam in vita futura per fidem expectamus" (De summo bono p. 372).

48 "[...] sicut omnia sunt ex hac causa, sic omnia ad ipsam ordinantur; nam ens illud in quo principium a quo omnia, coniungitur fini, ad quem omnia" (ibid. p. 376). Cfr. SCG III, 17: "Agens autem primum rerum omnium est Deus [...] Omnia igitur ordinantur in Deum sicut in finem"; Cfr. nota 36, acima, onde a formulação ainda mais se assemelha. 
primeiro é causa da produção, da ordenação e da conservação dos demais entes e, logo a seguir, mostra como os conserva na existência, classificando-os em três grupos: as substâncias separadas, os corpos celestes e os seres existentes sob o orbe. ${ }^{49}$ Tomás inicia seu tratado falando de Deus, perfeito no ser, no causar e no governar, para, de imediato, de modo menos aristotélico, dizer que governa os entes que possuem razão, os corpos celestes, não sujeitos à corrupção, e os corpos corruptíveis. ${ }^{50}$ Outras aproximações poderiam ainda ser apontadas, como a da relação entre perfeição e proximidade do primeiro princípio, ou a da unidade e bondade do mundo como participação na bondade primeira, mas para tais cotejos requerem-se certa dose de prudência e análise mais detalhada, a fim de evitar que se tome como dependência de um autor ante outro algo que é comum a toda uma época e que, por isso, coloca a ambos como dependentes de fonte anterior.

Limitando-se aos horizontes da Faculdade de Artes, Boécio de Dácia apresenta uma paráfrase ao tema aristotélico da eudaimonia, tal como desenvolvido principalmente na Ética a Nicômaco. A introdução inicia falando do bem maior possível de cada espécie, para dizer que o bem específico do homem se relaciona com sua virtude superior, divina mesmo, que é o intelecto. $O$ passo seguinte, porém, interpreta a seu modo o pensamento do mestre. Aristóteles, como vimos, parece oscilar ao definir a felicidade: por vezes diz que ela se encontra no viver segundo a virtude, por vezes, na contemplação da verdade. Boécio observa que o intelecto possui duas funções diferentes: a especulativa e a prática, e para cada uma delas existe uma operação específica que lhe é o bem supremo. Para o intelecto especulativo, este bem encontra-se na contemplação da verdade e no gozo dela proveniente. Entrementes, 0 intelecto prático encontra-o no exercício do bem e no deleite no mesmo. ${ }^{51}$ A distinção entre os dois intelectos serve-lhe, pois, para unificar a aparente dualidade aristotélica: a operatio secundum virtutem e a contemplatio são duas faces de um mesmo intelecto à procura do bem supremo.

Prosseguindo, recorda a frase com que se inicia a Metafísica, segundo a qual todos os homens desejam naturalmente conhecer. $\mathrm{O}$ conhecimento pertence, portanto, à natureza do homem, é o que ele possui de específico e de mais elevado: de específico, enquanto não o compartilha com os outros animais; de mais elevado, por tratar-se de algo que é próprio do intelecto, não dependendo formalmente da corporalidade. Ora, a unidade do ser humano, como vemos, exige que nele exista uma hierarquia, ficando as coisas inferiores sujeitas às superiores. Por isso, a vida vegetativa está em função da sensitiva e esta, em função da racional. E, na vida racional, as virtudes novamente se ordenam, em vista daquela que é superior às demais: o intelecto. Por isso o filósofo, como aquele que observa esta ordem

49 "[...] haec prima causa est causa productionis entium, sic et ordinationis eorum ad invicem e conservationis eorum in esse, quorundam secundum suum numerum et sine omni transmutatione, sicut substantiarum separatarum, et quorundam secundum numerum suum, tamen cum tmasmutatione, sicut corporum caeli, et quorundam secundum suam speciem tantum, sicut sunt illa quae sub orbe sunt, sicut sunt infimus gradus entium" (ibid. p. 376). SCG III, 1.

51 "Ex is quae dicta sunt manifeste concludi potest quod summum bonum quod est homini possibile est cognitio veri et operatio boni et delectatio in utroque" (ibid. p. 271). 
hierárquica das virtudes, encontra-se no melhor estado que é possivel ao homem, e "todas as virtudes, que nele se encontram, operam segundo a ordem natural". ${ }^{52}$

Fiel à tradição grega, Boécio afirma que o filósofo também é moralmente virtuoso, tanto porque conhece a torpeza das más ações e a nobreza das boas, como porque após haver experimentado os deleites superiores, encontra-se em melhor condição de desprezar os inferiores, como também porque nas ações intelectuais, por serem simples, não existe a deficiência ou o excesso. Mas o intelecto humano acha-se sempre em potência para novos conhecimentos, e quanto mais elevados eles são, tanto mais deseja conhecer. Por isso, o filósofo é levado naturalmente do conhecimento dos efeitos para o das causas, e do conhecimento das causas inferiores, ao conhecimento da causa suprema, eterna, incomunicável e sempre idêntica em seu modo de ser, perfeita, una e boa, e fonte de toda a perfeição, de toda a unidade, de toda a bondade.

Conhecendo o primeiro princípio, e sabendo que dele lhe provêm todos os bens, o filósofo é levado a amá-lo de forma suprema, pois amamos ao máximo aquilo de onde nos provêm os bens mais excelentes.

Boécio consegue manter-se fiel a Aristóteles? - A resposta depende do que se entende por fidelidade. O mestre da Faculdade de Artes, ao parafrasear o pensador grego, defrontou-se com toda a pujança do pensamento tomista, e aceitou-lhe 0 argumento de que "o desejo de conhecer somente fica saciado quando se conhece 0 infinito".$^{53}$ Ora, esta idéia distancia-se do pensamento do Filósofo, e introduz nele a cunha fatal, a separar a felicidade possivel da vida terrena da felicidade perfeita da outra vida. A conclusão do texto poderia ser mesmo interpretada como o reconhecimento dos limites à Filosofia, ou como a pretensão de transformar o conhecimento filosófico em equivalente ao teológico, ao ser dito que "o filósofo é aquele que chegou ao fim último e ótimo da vida humana [...], que é o Deus glorioso e sublime, bendito pelos séculos". ${ }^{54}$

Sob outro ângulo de vista, porém, o sabor teológico do texto é perfeitamente compreensivel. Na Idade Média, tanto a Filosofia cristã, como a árabe e a judaica, desenvolveram-se dentro de um mundo cultural sobredeterminado pelo religioso. Todas as três colocaram-se problemas idênticos e encontraram respostas semelhantes. Ao aceitar-se como filosoficamente demonstrável a existência e a perfeição de Deus, a criação do mundo e a imortalidade da alma, torna-se de todo possivel, sob o ponto de vista filosófico, e usando argumentos aristotélicos, falar de uma felicidade perfeita na outra vida. A fidelidade a Aristóteles estaria garantida graças à atualização: se ele vivesse no ano de 1270 , teria reagido a estas questões como os demais pensadores daquele tempo.

Mas o texto vai além. Há algo não expresso que lhe é primordial. O século XIII, desde a primeira década, conheceu uma tensão, com momentos de ruptura, entre o saber teológico e o saber filosófico. A autoridade eclesiástica, acionada

52 "Unde omnes virtutes quae sunt in philosopho operantur secundum ordinem naturalem" (ibid. p. 374).

53 "numquam enim satiatur appetitus sciendi, donec sciatur ens increatum" (ibid. p. 375).

54 "Philosophum autem voco [...] qui acquisivit optimum et ultimum finem vitae humanae. Primum autem principium, de quo sermo factus est, est Deus gloriosus et sublimis, qui est benedictus in saecula saeculorum. Amen" (ibid. p.376). 
pela Faculdade de Teologia, ou através desta, encarou com grandes reservas o trabalho desenvolvido na Faculdade de Artes. O que se presenciava então era uma nova cultura, com outros valores, da qual brotava o projeto de uma Filosofia autônoma. A Filosofia, não mais como propedêutica, mas como profissão, como a praticaram Platão, Aristóteles e os estóicos, sendo que estes, para tanto, usavam até vestes diferentes, voltava a ser apresentada aos acadêmicos cristãos. O De summo bono é a proposta de retomar o ideal antigo de vida filosófica, como um valor em si mesmo, independente das pretensões provenientes da Teologia. Tratava-se, sem dúvida, de um projeto arrojado, que custou caro a seus defensores, mas que os aproximou do nosso modo de praticar a Filosofia.

\section{4 - Conclusão}

O que a conclusão deve sintetizar, encontra-se nas observações feitas quanto ao modo como Agostinho, Tomás de Aquino e Boécio de Dácia adonaram-se do pensamento grego. $\mathrm{O}$ presente texto, que pretendeu acompanhar o desenvolvimento de uma idéia durante séculos, chegou à conclusão já apontada por outros: quando se comparam períodos diferentes do pensamento filosófico, as mesmas palavras, as mesmas imagens, as mesmas técnicas acadêmicas, os conceitos semeIhantes podem facilmente enganar quem os examina: há mundos diversos escondidos atrás deles. Aristóteles, Platão e Sêneca, quando assumidos pelos medievais, não foram apenas relidos dentro da parcialidade hermenêutica de cada intérprete, bem antes, foram recebidos dentro de categorias pré-críticas de um mundo cultural diferente. Na obra L'esprit de la philosophie médiévale, ${ }^{55}$ cuja primeira edição conta mais de 60 anos, E. Gilson, melhor do que ninguém, traçou um paralelo entre a Filosofia grega e a cristā. Após a leitura do livro fica uma pergunta: os medievais estavam mais próximos dos gregos ou dos modernos?

55 Paris: Vrin, 3a. ed. 1978. 